\title{
«Det er lett å se hvem av dere som har god innsats». Om elevers innsats og lærerens blikk i kroppsøving
}

\author{
Erik Aasland ${ }^{1 \star}$, og Gunn Engelsrud ${ }^{2}$ \\ ${ }^{1}$ Høgskolen $i$ Oslo og Akershus, Norway; ${ }^{2}$ Norges Idrettshøgskole, Norway
}

\begin{abstract}
Abstrakt
Bakgrunn: Vurdering av elevers innsats i kroppsøving har aktualitet både faglig og politisk. Det finnes likevel relativt lite forskningskunnskap om hvordan innsats giøres i praksis. Noen studier indikerer imidlertid at kroppsøvingslærere oppfatter og bruker innsats på ulike måter i undervisning og elevvurdering.

Forskningsspørsmål: Hvordan konstitueres innsats i kroppsøvingsundervisning?

Metodologi: Diskursteori inspirert av Michel Foucault brukes som rammeverk for feltarbeid og analyser. Fra et omfattende materiale produsert gjennom feltarbeid ved fire videregående skoler i Oslo, anvendes tre situasjoner fra to lærere. Begrepene eksaminasjon og klinisk blikk brukes i analysen av hvordan innsats kommer til uttrykk i undervisningen.

Funn: Overordnet viser våre analyser at innsats blir noe læreren «lett kan se». God innsats uttrykkes som at elevene «står på» slik at de blir drivende svette, at de forbedrer seg, samt at de fremviser positiv innstilling slik at de bidrar til å gjøre andre gode.

Diskusjon og konklusjon: Når læreren gir det de «ser» forrang i vurdering av elevers innsats, blir elevens synlige aktivitet tillagt stor vekt. Andre (lære-) prosesser og refleksjoner som foregår $i$ og mellom elever kan bli unndratt lærerens forståelse av elevene, med fare for å innskrenke alternative måter å forstå elevers innsats i kroppsøving.
\end{abstract}

Nøkkelord: Kroppsøving; innsats; blikk; diskursanalyse; Foucault

\begin{abstract}
Background: Evaluation of effort in physical education is of current interest, both in a professional, and a political context. There is still relatively little research on how effort appears in physical education teaching practice. Some studies suggest, though, that PE teachers perceive and implement effort in a variety of practices during teaching and student evaluation in PE.

Research question: How is effort constituted in PE teaching?

Methodology: Discourse theory inspired by Michel Foucault is used as a framework for fieldwork and analysis. The situations of two teachers are applied, drawn from extensive fieldwork material collected from four secondary schools in Oslo. The labels examination and clinical gaze are used to analyse how (effort is expressed during teaching) teachers identify and avail efforts in teaching.
\end{abstract}

^Korrespondanse: Erik Aasland, Høgskolen i Oslo og Akershus, Norway. Email: erik.aasland@ hioa.no

(C) 2017 E. Aasland og G. Engelsrud. This is an Open Access article distributed under the terms of the Creative Commons Attribution 4.0 International License (http://creativecommons.org/licenses/by/4.0/), allowing third parties to copy and redistribute the material in any medium or format and to remix, transform, and build upon the material for any purpose, even commercially, provided the original work is properly cited and states its license. 


\section{E. Aasland og G. Engelsrud}

Findings: Generally, our analyses show that effort appears as something easily discernible by the teacher. A full effort appears when the students "work hard», when the students correct themselves, and exhibit a positive attitude that prompts fellow students to do their best.

Discussion and conclusion: When the teacher gives apparent accomplishments primacy when assessing effort, the student body's visible activity becomes considerably more important. Other (learning) processes and reflections that occur within and in-between students risk being exempted from the teacher's evaluation, increasing the likelihood of curtailing alternative ways to recognize the students' efforts in physical education.

Keywords: Physical education; effort; gaze; discourse analysis; Foucault

Received: November 2016; Accepted: May 2017; Published: September 2017

\section{Introduksjon}

«Kom igjen! Stå på! Jobb hardere!» Alle som har vært elever i kroppsøving vil sikkert kunne gjenkjenne slike tilrop fra kroppsøvingslæreren. I materialet ${ }^{1}$ som denne artikkelen bygger på, var slike utsagn typiske, og både lærere og elever koblet ofte det å «jobbe hardt» til innsats. En slik kobling mellom innsats og «jobbe hardt» virker å være innarbeidet i kroppsøving (Biddle \& Goudas, 1997; Melograno, 2007). Slik vi ser det blir slike koblinger og meningssammenhenger skapt av diskurser (Börjesson, 2003). Det betyr at når læreren ser at elevene «jobber hardt» i undervisningen, vil bestemte diskurser virke slik at det framstår logisk og normalt for læreren (og elevene) å oppfatte den intensive aktiviteten (jobbe hardt) som «god innsats».

Noen nylig publiserte masterstudier viser at «god innsats» forbindes med elevers positive innstilling til læringsaktivitet (Uldalen, 2016; Øyehaug, 2016). At innsats kommer til uttrykk på forskjellige måter i undervisningen kan indikere at læreren trekker på/bruker ulike diskurser når innsats konstitueres (Larsson \& Nyberg, 2016; Redelius, Fagrell, \& Larsson, 2009). Konstitueringen av innsats blir særlig synlig gjennom lærernes utsagn og handlinger, og av den grunn blir læreren det sentrale omdreiningspunkt i vår studie. Samtidig har vi et øye på elevene, fordi «virkningene» av hva læreren sier og gjør relatert til innsats vil uttrykkes gjennom elevenes handlinger og ytringer. Med bakgrunn i dette har vi formulert følgende forskningsspørsmål:

Hvordan konstitueres innsats i kroppsøvingsundervisning?

Spørsmålet har aktualitet både faglig (Leirhaug, 2013, 2016) og politisk (Udir, 2006, 2012), noe som kommer fram når vi presenterer studiens kontekst.

\section{Studiens kontekst}

Det har vært en innarbeidet praksis hos norske kroppsøvingslærere å bruke en tredeling - innsats/holdning, ferdigheter og kunnskap - når elevene vurderes i kroppsøving (Arnesen, Nilsen, \& Leirhaug, 2013). Da Kunnskapsløftet ble innført i 2006,

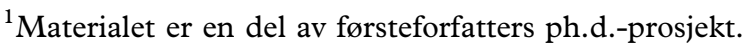


ble innsats fjernet som en del av vurderingsgrunnlaget i kroppsøving. Denne endringen bidro til å skape usikkerhet og frustrasjon blant lærere og elever (Prøitz \& Spord Borgen, 2010). Læreres usikkerhet, og en rekke medieoppslag relatert til vurdering i faget, bidro til at læreplanen i kroppsøving ble revidert, og det ble forskriftsfestet i opplæringsloven at innsats (igjen) skulle telle med i elevens karakter i kroppsøving (Udir, 2012). Et utdrag av denne lyder:

Innsats i faget kroppsøving innebærer at eleven prøver å løse faglige utfordringer
etter beste evne uten å gi opp, viser selvstendighet og utfordrer egen fysiske
kapasitet. Det innebærer at eleven samarbeider med andre og bidrar til at andre
lærer i faget. ... Ved å gjøre innsats til en del av grunnlaget for vurdering ... kan
elever ha mulighet til å oppnå en god karakter i faget til tross for lav kompetanse og
med forutsetninger som gjør det vanskelig å ha høy måloppnåelse. (Udir, 08/2012)

Sistnevnte formulering indikerer at det finnes normer $\mathrm{i}$ «kroppsøvingskulturen» ${ }^{2}$ for hva som anses som lav/høy kompetanse i kroppsøving (Biddle \& Goudas, 1997; Evans, 2004). Flere studier viser at slike elevkategoriseringer får betydning for hvordan innsats brukes i undervisning og karaktersetting (Brookhart, 1993; Mørck Vad, 2016; Uldalen, 2016). Ifølge Brookhart (1993) vil lærere være tilbøyelige til å sette en dårligere karakter enn prestasjonen i seg selv skulle tilsi dersom sterkt presterende elever ikke gjør så godt de kan. Motsatt, vil lærere med større sannsynlighet gi lavt presterende elever, som gjør så godt de kan, bedre karakter enn det de fortjener (Brookhart, 1993). Videre vil kroppsøvingslærere ifølge Mørck Vad (2016, s. 89) være tilbøyelige til å bruke innsats i undervisningen til å tvinge «høyt presterende elever» til deltagelse hvis nødvendig, mens overfor «lavt presterende elever» er lærere mer tilbøyelige til å bruke innsats til å motivere og oppmuntre til aktivitet og deltagelse $\mathrm{i}$ undervisningen (Mørck Vad, 2016; Uldalen, 2016).

Utover elevens arbeidsinnsats har også faktorer som oppmøte og punktlighet, riktig bekledning, holdninger/entusiasme, kunnskap og ferdigheter blitt vektlagt når lærere setter karakterer i kroppsøving (Annerstedt \& Larsson, 2010; Melograno, 2007). Lignende funn er sentrale i Redelius et al. (2009) sitt materiale. Elevenes karakterer baseres på resultater i målbare tester og hvordan de oppfører seg i undervisningen. Det gjelder å være disiplinert, vennlig, og utstråle en holdning om at kroppsøving er gøy. Disse studiene viser at det er noe annet utover elevenes kunnskaper som tildeles verdi av lærerne i praksisfeltet (Annerstedt \& Larssons, 2010; Redelius et al., 2009). En slik elevvurdering foretas til tross for at de svenske læreplanene stipulerer at det utelukkende er elevenes kunnskaper som skal vurderes. Ovennevnte studier viser at elevers innsats har betydning når lærere setter karakter i kroppsøving. Samtidig ser vi at lærerens vurdering og kategoriseringer av elevens kompetanse (lavt/høyt presterende) får betydning for hvordan lærere vurderer og bruker innsats. Slike kategoriseringer vil ifølge Börjesson (2003) være diskursivt konstruert, og vil framstå som logiske og i

\footnotetext{
${ }^{2}$ Kroppsøvingskulturen refererer til læreplanskribenter, forskere, lærerutdannere, lærere og elever i kroppsøving.
} 


\section{E. Aasland og G. Engelsrud}

overensstemmelse med den verden lærere og elever lever i. Diskurs er således et sentralt begrep i artikkel, og vi vil i det forestående redegjøre for hvordan vi bruker diskursbegrepet i studiens analytisk rammeverk.

\section{Analytisk rammeverk}

Når vi har valgt å betrakte undervisning og innsats som diskursive praksiser, så betyr dette ifølge Foucault (1972, s. 49) at diskursen er praksiser som former det objektet det tales om. For oss betyr det at interessen rettes mot hvordan innsats (objektet) konstitueres gjennom lærerens (og elevenes) utsagn (språk/kategorier) og handlinger i undervisningen.

Ifølge Foucault (1978) vil makt-kunnskapsrelasjoner som gjennomsyrer diskursen bidra til å normalisere bestemte oppfatninger og handlemåter. Begrepet normalisering får fram at individet kan beskrives, sammenlignes og sorteres med tanke på hva som til enhver tid regnes som en norm. Normalisering koblet sammen med blikket, kalles eksaminasjon (Foucault, 1999). Eksaminasjon gjøres ved bruk av et normaliserende blikk som gjør individene synlige. Det lar seg dermed gjøre å konstituere individet som et objekt som lar seg beskrive, analysere og sanksjonere (Foucault, 1999). Konstitueringen av individet som et objekt oppstod, ifølge Foucault (2000), ved inngangen til det 19. århundre. Den nye kliniske legevitenskapen som da oppstod la avgjørende vekt på det synlige (ved sykdom), og det kliniske blikket ble i langt større grad enn tidligere oppmerksom på individuelle og avvikende trekk. Det kliniske blikket bidrar til å skape distanse og avgrense kroppen til et objekt det er mulig å undersøke i et spenningsfelt mellom det som oppfattes henholdsvis som avvik og det generelle/ normale (Foucault, 2000).

Relatert til kroppsøving vil det som anses normalt bero på diskursen(e) som er tilgjengelige i dette feltet. Flere forskere har blant annet identifisert det de kaller en aktivitetsdiskurs i undervisningspraksiser i kroppsøving (Larsson \& Nyberg, 2016; Öhman \& Quennerstedt, 2008). Når en slik diskurs virker, forventes det at elevene er i aktivitet, helst med høy intensitet (Aasland, Walseth, \& Engelsrud, 2017). Dette poengteres i Marie Öhmans (2007) doktorgradsavhandling hvor hun viser at lærerne anvender tilrop som for eksempel; «bra jobbet!», «kjempebra!» og «kom igjen!» som teknikker for å frembringe ønskverdige handlinger hos elevene. Slike handlinger vises som en vilje til å fremvise høy aktivitet, en vilje til å forsøke, og en vilje til å gjøre sitt beste i undervisningen (Öhman, 2007) - med andre ord «å vise innsats». Selv om aktivitetsdiskursen har vært toneangivende i materialet til de svenske forskerne, har også idretts-/prestasjonsdiskurser (Tinning, 2010) og militærdiskursen (Augestad, 2003; Kirk, 2010) blitt identifisert i fagets praksis. Slike diskurser vil derfor medvirke til at det framstår legitimt og normalt at lærere vektlegger prestasjonsforbedring og disiplin i undervisning og elevvurderingen i kroppsøving.

Hos Foucault er blikk/observasjon, normalisering, og eksaminasjon (1999) disiplinærteknikker der kroppen blir gjenstand for maktutøvelse. En særlig effektiv maktteknikk er det panoptiske prinsipp (Foucault, 1999). Det panoptiske prinsipp er innrettet slik at den observerte overtar den andres blikk i overvåkningen av seg selv. 
Elever vil, dersom vi velger å følge Foucault, kunne tenkes å bedrive en form for selvdisiplinering/-overvåkning, fordi de vet at læreren vurderer deres innsats. Eleven vil $i$ et slikt perspektiv kunne ses som en som «overtar» blikket læreren bruker når elevene vurderes i undervisningen (Palm, 2014; Sivenbring, 2016).

\section{Empirisk kontekst og metode ${ }^{3}$}

Materialet i artikkelen er produsert gjennom feltarbeid ved fire videregående skoler i Oslo. Samlet sett består materialet av data fra observasjon av 92 undervisningsleksjoner samt et kvalitativt intervju av hver av de åtte lærerne. Det å skape et materiale fra et diskursperspektiv, vil ifølge Börjesson (2003) innebære å forsøke å se det underlige i det som framstår som normalt, en kunst i å fange det som tas-for-gitt. Dette blir særlig utfordrende når det er ens egen kultur ${ }^{4}$ som undersøkes, fordi forskeren da vil dele mange av de samme tatt-for-gitt oppfatningene som feltet som studeres preges av. Eksempler på dette vil være å se det som normalt at elevene skal være i mye aktivitet, at elevene forsøker/giør sitt beste i undervisningen, og at eleven skal vise god innsats for å oppnå god karakter i kroppsøving.

I feltarbeid kommer egne forforståelser til uttrykk, og ifølge Jørgensen og Phillips (2002) er dette noe man som forsker ikke kan fri seg fra. For å prøve å «få øye på» det som oppfattes som naturlig og meningsfullt i kroppsøving kan teoretisk perspektiv, slik Jørgensen og Phillips (2002) argumenterer for, brukes som en måte å skape distanse til egen hverdagsforståelse. Diskursperspektivet kan fungere slik, da det innebærer en interesse for å utforske hvilke «regler», normer, og logikker som er i spill (Nerland, 2003). Dette perspektivet var med fra starten og ga noen rammer for feltarbeidet (Järvinen \& Mik-Meyer, 2005). I tråd med ph.d.-prosjektets forskningsspørsmål, og det valgte perspektivet, ble følgende spørsmål styrende for hvordan det empiriske materialet ble produsert: Hvilke begreper brukes, og hvilke gjentas ofte? Hvilke elevhandlinger igangsettes av lærerens utsagn og handlinger, og hvordan? Presenteres mål/tema for undervisningen, og hva er i så fall det? Hva og hvordan korrigerer/roser læreren elevenes handlinger, og hva skjer eventuelt da?

Jeg (førsteforfatter) forsøkte å notere så mye som mulig av det som ble sagt og giort i undervisningen med tanke på å identifisere «reglene» som gjør at «kroppsøving» kan gjenkjennes. Det var imidlertid flere situasjoner i undervisningen som bidro til å trekke oppmerksomheten bort fra «reglene» og logikkene som en ifølge teorien skulle se etter. Jeg ble til tider provosert av situasjoner der jeg reagerte på at læreren (kun) igangsatte det jeg oppfattet som «ren» treningsaktivitet, og hadde lett for å tenke på læreren som en «kontrollør» av elevers aktivitetsnivå i undervisningen. Andre ganger derimot var min oppmerksomhet rettet mot lærere som gjennomførte undervisningsopplegg jeg anså som kreative og vel gjennomtenkte. Også alle elevene,

\footnotetext{
${ }^{3}$ Studien er meldt inn og godkjent hos NSD. Lærerne ble informert skriftlig og muntlig om studiens hensikt og metoder, og ga skriftlig samtykke på at de ville delta i undersøkelsen. Rektor ved de respektive skolene, samt elevene som deltok i observasjonen, ble informert muntlig om studien.

${ }^{4}$ Begge forfatterne er tidligere lærere og elever i faget, og jobber som lærerutdannere i kroppsøving.
} 


\section{E. Aasland og G. Engelsrud}

med sine ytringer og måter å være på i undervisningen, bidro til at mitt forskerblikk til tider ble dratt i andre retninger enn det som skulle være observasjonsfokus. Å være åpen overfor det som skjer er imidlertid en måte forskeren kan trene sin refleksivitet og være selvkritisk til egne fordommer.

Observasjoner ble også komplettert med kvalitative intervjuer av lærere. Intervjuene foregikk med utgangspunkt $\mathrm{i}$ en intervjuguide, og tok ofte utgangspunkt $\mathrm{i}$ situasjoner jeg hadde observert i undervisningen. Disse situasjonene ble lærerne bedt om å kommentere eller utdype. Intervjuene handlet også om hva lærere oppfatter som viktige kunnskaper og ferdigheter $\mathrm{i}$ faget, og hva som kjennetegner en dyktig og mindre dyktig elev i kroppsøving.

I analysen følges Carabines (2001) forslag til å gjøre Foucault-inspirert diskursanalyse. Innsats framstod i observasjonene som et sentralt fenomen i alle lærernes undervisning, og det første formelle steget i analysen var å få oversikt over de deler av materialet hvor innsats forekom. Det ble et relativt omfattende material og for denne artikkelens formål bestemte vi oss for å bruke tre situasjoner. Vi ser analysene av de tre situasjonene, i kombinasjon med diskursperspektivet, som egnet til å «pakke ut» hvordan innsats konstitueres i undervisningspraksis. Disse situasjonene diskuteres i lys av forskning for å vise hvordan lærere bruker/trekker på ulike diskurser i deres måte å gjøre innsats. I de tre situasjonene bruker vi to lærere. De to lærerne benevnes Lerer 1 på gul skole og Lerer 2 på rød skole.

\section{Funn}

Hovedfunnet som binder våre analyser sammen er at elevens innsats er noe lærere ser. Vi har organisert våre funn som tre måter innsats kommer til uttrykk på: Det er lett $a$ se hvem som står på slik at de blir drivende svette, det som kan ses i forhold til framgang, og jeg ser på innstilling. Du skal vare lagspiller og gjøre andre gode.

\section{Det er lett å se hvem som står på slik at de blir drivende svette}

Innsats uttrykkes gjennomgående som at elevene skal jobbe hardt i undervisningen. I situasjonen nedenfor foregår undervisningen i skolens styrkesal. Lærer 1 starter leksjonen med å informere (skriver på tavlen samtidig som hun prater) om hvilke øvelser elevene skal utføre, samt antallet repetisjoner som skal gjennomføres. Litt seinere i timen kommer læreren bort til meg (førsteforfatter) og sier:

Lærer 1: Det er lett å se hvem av elevene som virkelig står på og gjennomfører treningen. Han eleven der (peker på en elev) for eksempel er drivende svett hver gang.

Når jeg spør hvordan en slik økt vurderes, svares det slik:

Lærer 1: Jeg vurderer innsats på hvordan økten gjennomføres, pluss litt teknikk

Læreren trekker fram eleven som svetter som eksempel på hvem som står på, og hva det vil si å ha god innsats. Det å stå på og bli svett framstår logisk og normalt i denne settingen. Her er læreren på linje med det Larsson og Nyberg (2016), Öhman og 
Quennerstedt (2008) og Öhman (2007) har fått frem i sin forskning - at fysiologi-/ aktivitetsdiskursen virker slik at lærere (og elever) gir aktiviteten, og effekten av denne, forrang i kroppsøvingen. I slutten av timen samlet læreren alle elevene foran seg og sa:

Lærer 1: Det er lett å se hvem av dere som har god innsats. Det er ikke for å være slem med dere at dere må gjøre dette (peker på tavlen med styrkeøvelser og smiler), det er for at det er bra for dere. Og det er lov å bli sliten. Da blir det mindre slitsomt neste gang.

Når læreren sier at «det ikke er for å være slem at dere må gjennomføre trening med hard intensitet» brukes her kunnskap fra treningsfysiologi for å legitimere at elevene må jobbe hardt. Ved å poengtere at det ikke er «for å være slem», modererer læreren en kommandantrolle kjent fra en militær diskurs (Augestad, 2003; Kirk, 2010) og legitimerer i så måte at virkemidlet (slem lærer) ikke må stå i veien for sluttresultatet (bra for dere å bli slitne). For at elevene skal få den gode (helse-)effekten, kan vi si at målet helliger midlet.

Læreren sier også at «det er lett å se hvem som har god 'innsats'». Utsagnet tydeliggjør noe som ble hørt flere ganger, og som vi selv kjenner oss igjen i. Elevenes kropper blir lett synlige i en kroppsøvingstime. Ved å bruke blikk og eksaminasjon som analytiske begrep, får vi fram at det læreren ser blir viktig for å identifisere innsats. Elevene får høre at det er lett å se hvem som har god innsats og at læreren har gjort seg opp en mening om hvem det gjelder. På denne måten blir elevene klar over at læreren følger med på hva de gjør i timen. De stilles i en posisjon der de selv kan vurdere om de skal vise god innsats når læreren ser på dem (Palm, 2014; Sivenbring, 2016). Aktiviteten til mange av elevene ble redusert, eller opphørte, når læreren $i k k e$ hadde blikket sitt på dem. Hver gang læreren snudde seg mot elevene økte intensiteten umiddelbart. Med Foucault (1999) kan vi si at innsats her blir noe som konstitueres ved bruk av lærerens blikk. Det er et blikk som ser etter det som oppfattes som det normale, og som gjør det mulig å klassifisere elevene etter god eller dårlig innsats. Når elevenes handlinger igangsettes som effekt av lærerens blikk, gis læreren mulighet til å bruke innsats for å oppnå bestemte hensikter. Hvis hensikten er at elevene skal delta aktivt med høy intensitet (Öhman, 2007), vil læreren kunne minne elevene på at de vurderes på innsats. På denne måten blir utsagn om innsats, i kombinasjon med et vurderende blikk, noe som skaper elevenes jobbing i undervisningen. For å utvikle dette videre skal vi vise en situasjon der også Lærer 2 trekker inn hvordan elevers innsats er noe som ses.

\section{Det som kan ses i forhold til framgang}

Lærer 2 kommer inn på at det som ses av forbedring gjennom skoleåret har betydning for hvor bra «skåren på innsats» blir:

Lærer 2: Jeg tenker at det kan være litt sånn, todelt på en måte. Du har innsats, det som man ser i timen. At de jobber hardt i timen. Og så har man det som man liksom kan se i forhold til framgang. Sånn som de tolket det før innsats kom tilbake, at de ser at her må det ligge innsats bak, plutselig forbedret seg, så det arbeidet de 


\section{E. Aasland og G. Engelsrud}

gjør imellom. Og derfor så tenker jeg at man ikke skal være så redd for å kjøre tester. Hvis man gjør det (bruker tester), bruker det på riktig måte, så er det veldig motiverende for mange. Det der å se framgangen, svart på hvitt. Uten at det knyttes veldig opp mot karakterer.

På den ene siden ser Lærer 2 innsats som det at elevene skal jobbe hardt $i$ timen, tilsvarende Lærer 1 sitt utsagn i forrige avsnitt. I tillegg trekker Lærer 2 fram at innsats handler om «det man kan se i forhold til framgang». Utsagnet indikerer at graden av framgang vil være et uttrykk for elevens innsats. Læreren sier også at «man ikke skal være så redd for å kjøre tester», og et slikt utsagn er relevant i en praksis der elevenes forbedring av fysiske egenskaper (utholdenhet, styrke) er den opplagte hensikt (Larsson \& Karlefors, 2015). Læreren fremhever også betydningen av at testresultatet er framskaffet av klokken. Testresultater ved tidtaking, noe som her omtales som «svart på hvitt» får status som objektiv og «sikker» viten. Ifølge læreren vil det for mange elever være motiverende «å se framgangen». Utsagnet kan relateres til det Tinning (2010, s. 69) kaller performance discourses. Her vil sentrale begreper være treningsintensitet, måling, og prestasjonsframgang. Innvevd i en prestasjonsdiskurs blir det dermed opplagt og normalt at elevene skal trene for å oppnå forbedring på fysiske parametere. Når elever får synliggjort forbedring på tester framstår det derfor som legitimt at dette vil være gunstig for elevenes motivasjon.

Her får vi fram at innsats hos Lærer 2 både blir det som ses $i$ undervisningsleksjonene (jobbe hardt), og det som kan ses i form av framgang. Forbedring på fysiske parametere vil være vanskeligere å identifisere kun ved hjelp av det læreren ser, og da brukes andre hjelpemidler. Gjennom å bruke klokken til å måle elevenes tidsbruk på testen, får både læreren og elevene fram det som regnes som et pålitelig og objektivt resultat om, og i hvilken grad, en reell prestasjonsframgang har funnet sted. Trekker vi inn Markula og Pringle (2006) vil det å bruke testresultater for å dokumentere elevers grad av innsats kunne fungere som en form for overvåkning, designet for å kvantifisere og klassifisere elevenes utførelse i forhold til en forventet standard. Lærerens utsagn indikerer at det forventes at elevene forbedrer seg ved å legge ned nødvendig treningsarbeid mellom pre- og posttest. I så måte vil makten virke panoptisk (Foucault, 1999). Dette betyr at læreren ikke behøver å ha blikket på eleven hele tiden, da eleven kan ha internalisert at de overvåkes og blir målt på det treningsarbeidet de nedlegger mellom pre- og posttest. Med et slik perspektiv kan vi si at elevene selv overtar blikket læreren ser dem med. Gjennom at læreren vurderer grad av forbedring på tester som innsats, vil innsats kunne brukes på en slik måte at elevene «tvinges» til å «gjøre det nødvendige arbeidet i mellom». Dette impliserer at elevene, gjennom selvrefleksjon, vil måtte ta valg om de vil leve sitt liv (f.eks. egentrening utenom kroppsøvingen) på en slik måte at det vil resultere i bedre fysisk form målt $\mathrm{i}$ testresultater. Dersom de oppnår forbedring på testen, vil elevene, slik Lærer 2 bruker innsats, kunne oppnå høyere skåre på innsats, og antageligvis bedre karakter i kroppsøving. 
Jeg ser på innstilling. Du skal være lagspiller og gjøre andre gode.

I situasjonen vi viser til her, har Lærer 1 valgt fotball som tema i undervisningen. I første del av undervisningen gjennomføres det fotballrelaterte øvelser. To av guttene (som så ut til å ha spilt en del fotball fra før) kommer med en del negative kommentarer når teknikkøvelsene gjennomføres. Før læreren deler elevene i to lag og skal sette i gang spillet, samler læreren elevene på midten og sier:

Lærer 1: Husk at jeg vurderer dere. Noen av elevene: Hæ, kødder du?

Lærer 1: Nei, dere blir vurdert. Da nytter det ikke å sitte nede i hjørnet, og synes alt er kjedelig. Så jeg ser veldig mye på innsats. Innstilling. Jeg ser på hvis du er god til å spille så skal du være lagspiller og gjøre andre gode.

Læreren registrerer at noen elever viser misnøye ved gjennomgang av teknikk-øvelser, og minner derfor elevene på at de blir vurdert. «Det å sitte nede i hjørnet og synes alt er kjedelig» er ikke riktig innstilling, ifølge læreren. Utsagnet indikerer at selv om elevene synes undervisningsopplegget er kjedelig, så skal de likevel framvise en positiv innstilling (Öhman, 2007). Lærerens måte å bruke innsats på her sammenfaller med funnene til Mørck Vad (2016) og Øyehaug (2016), der innsats kobles til elevenes innstilling til undervisningsopplegget. Spesielt gjelder dette for de elevene som læreren vurderer som «sterkt presterende» (Uldalen, 2016). Dersom sterkt presterende elever framstår positive, vil dette kunne tenkes å bidra til at lærerens hverdag blir enklere, det vil si at det blir mindre utfordringer med disiplin.

Læreren ser hvem av elevene som er «gode til å spille», og forventer at disse elevene bidrar til å «gjøre andre gode». Her samsvarer lærerens forståelse og vurdering av innsats med Forskrift til opplæringsloven (Udir, 2012), hvor det står at innsats innebærer at eleven samarbeider med andre og bidrar til at andre lærer i faget. I tråd med Uldalen (2016) vil det også for Lærer 1 være slik at denne måten å framvise innsats på først og fremst gjelder de høyt presterende elevene (de som kommer i kategorien gode til å spille). Ser vi utsagnet «husk at dere blir vurdert» gjennom eksaminasjon kan vi tolke det som at læreren vet at vedkommende har «noe på lur», og dermed kan «straffe» de elevene som «sitter nede i et hjørne og synes alt er kjedelig» ved å gi dem dårligere skåre på innsats. Når læreren påminner de ballspilldyktige elevene om at de blir sett og blir vurdert etter i hvilken grad de bidrar til å gjøre andre gode, medvirker lærerens blikk til at ballspillgode elever samarbeider og opptrer slik læreren og Forskrift til opplæringsloven (Udir - 08 - 2012) foreskriver. Her trekker læreren på flere diskurser. $\AA$ «gjøre andre gode» relaterer vi til tankegods fra tidligere toppidrettstrenere som Nils Arne Eggen og Marit Breivik. Særlig er Eggen kjent for sin «Godfot-teori» som fremhever betydningen av at utøveren bruker sine ferdigheter slik at det kommer andre/laget til gode. Dessuten trekker læreren på en disiplindiskurs, slik også studien til Mørck Vad (2016) viser, når innsats blir et maktmiddel for at elevene skal oppføre seg slik det forventes.

Diskursanalytikere vil være opptatt av å vise hvordan og hvorfor «ting» fremtrer som de gjør (Neumann, 2001). Vi vil også diskutere mulige grunner til våre funn, og særlig den synlige aktivitetens forrang som uttrykk for, og vurdering av, innsats. 


\section{Diskusjon}

Ved at kroppen blir et objekt for aktivitet blir det synlig hvordan diskurser (Augestad, 2003; Öhman \& Quennerstedt, 2008; Tinning, 2010) bidrar til å normalisere og opprettholde rådende oppfatninger om hva som teller som innsats. Kroppene kan trenes forbedres og testes, og slike praksiser er godt kjent fra både fitnessindustrien, idretten og det militære. Forskning har vist at særlig en aktivitets-/fysiologidiskurs dominerer i undervisningen i kroppsøving (Aasland et al., 2017; Larsson \& Nyberg, 2016; Öhman \& Quennerstedt, 2008). En slik diskurs henter næring fra fag som fysiologi og treningslære som bidrar med viten om effekten av (intensiv) fysisk aktivitet på fysisk form og helse. Kunnskapen om sammenhengen mellom (fysisk) aktivitet og helse bidrar til at aktivitet blir det primære målet $\mathrm{i}$ undervisningen. Hvordan elevene beveger seg spiller mindre rolle, så lenge de beveger seg (Larsson \& Nyberg, 2016). Når læreren ser at eleven beveger seg mye, vil dette være indikator på god innsats. Elever som er passive, eller beveger seg lite, blir indikatorer på dårlig innsats. Dette betyr at for eksempel elevenes kroppslige erfaringer (kinestetisk og sansemessig), selvregulert læring, refleksjon og metakognisjon (Spord Borgen \& Engelsrud, 2015) vil være aspekter som faller utenfor lærerens vurdering av elevens innsats. Når de nevnte diskurser opprettholdes i fagets praksis, blir blant annet temaer som laring og elevmedvirkning underkommunisert i denne settingen (Leirhaug, 2016). Det vil kunne bety at en elev som ikke ses i aktivitet, men som aktivt reflekterer hvordan faglige utfordringer kan løses i undervisningen, vil risikere å skåre dårlig på innsats, fordi læreren først og fremst ser eleven som inaktiv. Å vurdere hvordan elever løser faglige utfordringer vil kreve andre vurderingsmåter enn det som kan ses av læreren. Men å tenke seg at kroppsøving skulle omformes til et «snakke- og refleksjonsfag», ville trolig representere et brudd i fagets praksis. Derfor vil trolig lærere (og elever) fortsette å «gjøre» innsats slik vi viser i vår studie. For lærere (og elever) vil en opplagt, normal og forståelig måte å gjøre innsats være det som kan ses av synlig aktivitet, det å forbedre seg, og bidra til å giøre andre (medelever) gode.

$\AA$ fremvise positiv innstilling til læringsaktiviteten er et annet punkt vi vil diskutere. Flere studier viser at andre forhold enn ferdigheter og kunnskaper får innflytelse på hvilken karakter eleven oppnår i kroppsøving (Annerstedt \& Larsson, 2010; Melograno, 2007; Redelius et al., 2009). Ifølge Annerstedt og Larsson (2010) virker det som om lærere har «internalisert» en slik vurderingspraksis, til tross for at styringsdokumenter foreskriver at læreren ikke skal vurdere annet enn elevens kunnskap. I vår studie virker det som at innsats omfatter slike «andre forhold» (jobbe hardt, vise god oppførsel, positiv innstilling) enn det som kan relateres til elevenes kunnskap og ferdigheter. Det synes derfor betimelig å spørre hva som kan være grunnen til at faktorer som innstilling eller det å oppføre seg bra, appellerer så sterkt til kroppsøvingslærere når de setter karakter i kroppsøving? Historisk sett har faget konstituert seg som et arnested for disiplinering av kroppen (Augestad, 2003; Kirk, 2010), og López-Pastor, Kirk, Lorente-Catalán, MacPhail, og Macdonald (2013) skriver at da faget omhandlet drill og eksersis, var et av hovedmålene å lære eleven konstant lydighet. 
Mange av fagets disiplinærteknikker var tilpasset datidens pedagogiske regime, et regime som skulle sørge for å fremme god oppførsel og karaktertrekk hos elevene (Augestad, 2003). Selv om kroppsøvingsfagets militære tilknytning har opphørt (i alle fall i læreplan), argumenterer Redelius, Quennerstedt og Öhman (2015) for at «gamle» tradisjoner og vaner «overlever» og forblir tilstedeværende $\mathrm{i}$ fagets nåværende undervisningspraksis. Det er således ikke urimelig å tenke seg at lærerens vurdering av elevenes oppførsel og innstilling er overlevninger fra datidens militærpraksiser. Når lærere vurderer elevenes oppførsel og innstilling som innsats, bidrar lærerens vurderingspraksis til at elevene pålegges en (selv-) overvåkning i henhold til hvordan de oppfører og ter seg i undervisningen (Palm, 2014; Sivenbring, 2016). En slik vurderingspraksis kan være problematisk, og våre funn bidrar til å klargjøre at læreren disponerer et maktmiddel overfor sine elever.

\section{Studiens troverdighet}

Hensikten med studien har vært å undersøke hvordan «innsats» konstitueres i undervisningspraksis i kroppsøving. Vi har forsøkt å være transparente gjennom å redegjøre for vårt analytiske perspektiv, samt hvilke spørsmål som ble brukt for å produsere empirisk materiale. Likeledes er våre valg av analytiske begreper fra Foucault bidragsytende for hvordan materialet blir lest og analysert. Når vi betrakter læreres utsagn og handlinger relatert til innsats som konstituert av diskurser, bidrar dette således til én bestemt fremstilling av innsats, samtidig som alternative perspektiver og forståelser kommer i bakgrunnen. Dette viser at også forskning må forstås som diskursiv praksis, og i så måte aktualiseres betydningen av forskerrefleksivitet hvor vi som forskere reflekterer over eget ståsted og hvordan dette påvirker forskningsprosessen (Nerland, 2004).

En svakhet kan være at vi kun har anvendt tre situasjoner fra to lærere i våre analyser. Vi er likevel av den oppfatning at ved å trekke fram disse, fikk vi «pakket ut» situasjoner vi synes var faglig spennende, $i$ og med at vi fikk brukt blikk, normalisering og eksaminasjon på en måte som fikk fram noe nytt i forskningen om innsats. Våre funn viser hvordan innsats konstitueres av diskurser som også er identifisert i annen forskning. I så måte gjenspeiler våre funn en legitim og gjenkjennelig måte innsats gjøres på i kroppsøvingsundervisning.

\section{Konklusjon}

Våre funn viser at innsats konstitueres gjennom det læreren ser og hvordan dette bidrar til å normalisere bestemte oppfatninger og handlemåter. Elevene vet også at for å «skåre bra» på innsats må de jobbe hardt, forbedre seg, og vise positiv innstilling gjennom å gjøre hverandre gode. Vi viser hvordan slike handlinger kan ses som en effekt av et klinisk blikk (Foucault, 2000). Med andre ord; innsats kobles til aktiviteter som blir synlig for lærerne. Det er hva den objektive elevkroppen framviser som teller som innsats. I så måte ser det ut som innsats bidrar til å opprettholde grunnleggende ideer og praksiser i faget. Slik vår diskusjon viser kan det være grunn til å stille 


\section{E. Aasland og G. Engelsrud}

spørsmål ved en slik praksis. Dersom kroppsøving skal medvirke til at elevene sanser, opplever, lærer og skaper med kroppen (jamfør formålet med faget) innebærer dette at andre forhold enn kun det synlige må få verdi når læreren ser og vurderer elevenes innsats i kroppsøving.

\section{Referanser}

Aasland, E., Walseth, K., \& Engelsrud, G. (2017). The changing value of vigorous activity and the paradox of utilizing exercise as punishment in physical education. Physical Education and Sport Pedagogy. doi: 10.1080/ 17408989.2016.1268590

Annerstedt, C., \& Larsson, S. (2010). «I have my own picture of what the demands are ...»: Grading in Swedish PEH - problems of validity, comparability and fairness. European Physical Education Review, 16(2), 97-115.

Arnesen, T.E., Nilsen, A.K., \& Leirhaug, P.E. (2013). «Den læreplanen som ikkje kan tilpassast mi undervisning, finst ikkje.» Vurdering og undervisning i kroppsøving etter Kunnskapsløftet. Tidsskriftet FOU i praksis, 7(3), 9-32.

Augestad, P. (2003). Skolering av kroppen. Om kunnskap og makt i kroppsøvingsfaget. Doktorgradsavhandling. Oslo: Universitetet i Oslo.

Biddle, S., \& Goudas, M. (1997). Effort is virtuous: teacher preferences of pupil effort, ability and grading in physical education. Educational Research, 39(3), 350-255. doi: 10.1080/0013188970390310

Börjesson, M. (2003). Diskurser och konstruktioner. En sorts metodbok. Lund: Studentlitteratur.

Brookhart, S.M. (1993). Teachers' Grading practices: Meaning and Values. Fournal of Educational Measurement, 30(2), 123-142.

Carabine, J. (2001). Unmarried Motherhood 1830-1990: A Genealogical Analysis. I M. Wetherell, S. Taylor, \& S. J. Yates (Red.), Discourse as Data. A guide for analysis (s. 267-310). The Open University: Sage publications.

Evans, J. (2004). Making a difference? Education and «ability» in physical education. European Physical Education Review, 10(1), 95-108.

Foucault, M. (1972). The Archeology of Knowledge and the Discourse on Language. New York: Pantheon Books.

Foucault, M. (1978). The History of Sexuality. Volume 1: An Introduction. New York: Vintage Books.

Foucault, M. (1999). Overvåkning og straff. Oslo: Gyldendal Akademisk.

Foucault, M. (2000). Klinikkens fødsel. København: Hans Reitzels forlag.

Jørgensen, M., \& Phillips, L. (2002). Discourse Analysis as Theory and Method. London: Sage.

Mik-Meyer, N., \& Järvinen, M. (2005). Indledning: Kvalitative metoder i et interaktionistisk perspektiv. I: Järvinen, M., \& Mik-Meyer, N. (Red.), Kvalitative metoder $i$ et interaktionistisk perspektiv. Interview, observationer og documenter (s. 9-24). Danmark: Hans Reitzels Forlag.

Kirk, D. (2010). Physical Education Futures. London \& New York: Routledge.

Larsson, H., \& Karlefors, I. (2015). Physical Education Cultures in Sweden: Fitness, Sports, Dancing ... Learning? Sport, Education and Society, 20(5), 573-587. doi: 10.1080/13573322.2014.979143

Larsson, H., \& Nyberg, G. (2016). «It doesn't matter how they move really, as long as they move.» Physical education teachers on developing their students' movement capabilities. Physical Education and Sport Pedagogy, 22(2), p.137-149. doi: 10.1080/17408989.2016.1157573

Leirhaug, P. E. (2013). Hvorfor innsats $i$ kroppsøving? Faglig blogginnlegg. Oslo: NIH.

Leirhaug, P. E. (2016). «Karakteren $i$ seg selv gir jo ikke noe laring». En empirisk studie av vurdering for lering $i$ kroppsøving ved seks videregående skoler $i$ Norge. Doktorgradsavhandling. Oslo: Norges Idrettshøgskole.

López-Pastor, V.M., Kirk, D., Lorente-Catalán, E., MacPhail, A., \& Macdonald, D. (2013). Alternative assessment in physical education: a review of international literature. Sport, Education and Society, 18(1), 57-76. doi: 10.1080/13573322.2012.713860

Markula, P., \& Pringle, R. (2006). Foucault, Sport and Exercise. Power, knowledge and transforming the self. London and New York: Routledge.

Melograno, V.J. (2007). Grading and report cards for standard-based physical education. Fournal of Physical Education, Recreation E Dance, 78(6), 45-53. doi: 10.1080/07303084.2007.10598041

Mørck Vad, A.M. (2016). Innsats og makt. En studie om kroppsøvingslareres forståelse og anvendelser av innsats og makt. Masteroppgave i idrettsvitenskap. Oslo: Norges Idrettshøgskole. 
Nerland, M. (2003). Instrumentalundervisning som kulturell praksis. En diskursorientert studie av hovedinstrumentundervisning $i$ høyere musikkutdanning. Avhandling for graden dr.polit. Pedagogisk forskningsinstitutt. Oslo: Universitetet i Oslo.

Öhman, M. (2007). Kropp och makt $i$ rörelse. Akademisk avhandling för filosofie doktorsexamen i sosiologi. Örebro: Örebro Universitet.

Öhman, M., \& Quennerstedt, M. (2008). «Feel Good - Be Good: Subject Content and Governing Processes in Physical Education». Physical Education and Sport Pedagogy 13(4), 365-379. doi: 10.1080/ 17408980802353339

Palm, T.A. (2014). Assessing with Foucault. A critical study of assessment in physical education. Master thesis in Sport Sciences. Oslo: Norwegian School of Sport Sciences.

Prøitz, T.S., \& Spord Borgen, J. (2010). Rettferdig standpunktvurdering - det (u)muliges kunst? Lareres setting av standpunktkarakter i fem fag i grunnopplaringen. Rapport 16/10. Oslo: NIFU STEP.

Redelius, K., Fagrell, B., \& Larsson, H. (2009). Symbolic capital in physical education and health: to be, to do or to know? That is the gendered question. Sport, Education and Society, 14(2), 245-260.

Redelius, K., Quennerstedt, M., \& Öhman, M. (2015). Communicating aims and learning goals in physical education: part of a subject for learning? Sport, Education and Society, doi: 10.1080/ 13573322.2014 .987745

Säljö, R. (2016). Lering - en introduksjon til perspektiver og metaforer. Oslo: Cappelen Damm Akademisk.

Sivenbring, J. (2016). I den betraktadas ögon. Ungdomar om bedømning $i$ skolan. Akademisk avhandling i Barn och ungdomsvetenskap, vid Institutionen för pedagogik, kommunikation och lärande. Göteborg: Göteborgs Universitet.

Spord Borgen, J., \& Engelsrud, G. (2015). Kroppsøvingsfaget som skolefag - 30 år frem i tid. Faglig blogginnlegg. Oslo: NIH.

Tinning, R. (2010). Pedagogy and Human Movement. Theory, Practice, Research. London and New York: Routledge.

Uldalen, I. (2016). Fått som fortjent? Lareres setting av standpunktkarakter $i$ kroppsøvingsfaget $i$ videregående skole når innsats er en del av vurderingsgrunnlaget. Masteroppgave i idrettsvitenskap. Oslo: Norges Idrettshøgskole.

Utdanningsdirektoratet (2006). http://www.udir.no/k106/KRO1-01/Hele/Kompetansemaal/etter-vg1

Utdanningsdirektoratet (2012). http://www.udir.no/k106/KRO1-04

Utdanningsdirektoratet (2012). https:/www.udir.no/Upload/Rundskriv/2012/Udir-8-2012- kroppsoving.pdf? epslanguage $=$ no

Øyehaug, H.K. (2016). «Innsats» $i$ kroppsøving $i$ ungdomsskolen. Ei kvalitativ intervjustudie av eit utval elevar om innsatsforskrifta $i$ kroppsøving. Masteroppgave i idrettsvitenskap. Oslo: Norges Idrettshøgskole. 